\title{
The Research on the Model Structuring of Supply Chain Finance Based on the Theory of Resource Orchestration
}

\author{
Xiaohui Wang \\ School of Economics and Management, Beijing Jiaotong University, Beijing 100044, China \\ 15125400@bjtu.edu.cn
}

\begin{abstract}
Based on the perspective of resource orchestration, through the case study of Shuhai supply chain, this paper explored how the traditional catering company through the dynamic orchestration to develop the financial business and established the evolution path of supply chain finance. According to the three steps of the theory of resource orchestration: resources structuring combination, bundling, and leveraging, this paper reviewed the Shuhai company transforming from the traditional supply chain service to develop the catering supply chain finance model dominated by core enterprises with the catering industry characteristics.
\end{abstract}

Keywords: resource orchestration; catering supply chain; supply chain finance.

\section{Introduction}

In the catering supply chain, accounts and funds became the biggest impediment. In 2015, there are companies developing dining supply chain finance [1], but methods and business models are several of each other. In the rapidly changing market, how to choose the right business model is a subject that is worth studying deeply and has practical significance.

\section{Study Design}

This paper mainly adopts the case study method to study how to develop financial supply chain and its model construction in the catering industry, chooses Shuhai Company as research object, and takes its behavior of the supply chain financial business as the research unit. As a subsidiary of the Haidilao Group, Shuhai has been in the leading position in the domestic chain food supply chain and has a higher degree of informationization, which meets the requirements of the principle of industry representative and the principle of data acquisition [2].This study used a variety of sources to collect data, mainly including: semi-structured interviews, field observation and secondary data collection, triangulation data is verified in two ways: based on multiple data sources and multiple respondents, and Screening out the credible data for analysis and coding [3].

\section{Case analysis}

\subsection{Stage in the Transformation of the Traditional Supply Chain Services}

After 20 years of development, Haidilao has become the catering leader in China. For the reasons of group strategic adjustment, Haidilao established Shuhai (Beijing) Investment Co., Ltd in 2011. Shuhai aims to build the catering supply chain service platform, provide catering customer with the security, stability and traceable third parties supply chain service for covering the entire catering service chain, and provide customers with the complete customized supply chain solutions [4].

Shuhai owns the ingredients coming throughout the country and the specialized logistics supply system. The mode of Central kitchen leads to the restaurant's high operating efficiency, high service standards and high operating profits. In the last five years, the great results in the information construction have made Shuhai a more competitive supply chain service provider [5].

In 2016 March, the supply chain coordination platform started to be put in use. With the implement of this platform, customers and suppliers could seek for cooperation on their own. This platform, focusing on catering industry, could also attract more supplies and customers, and join all the source 
of funds, purchasing, suppliers and professional third-party service organizations together [6]. The whole process is based on the theory of resource orchestration as shown in Fig1.

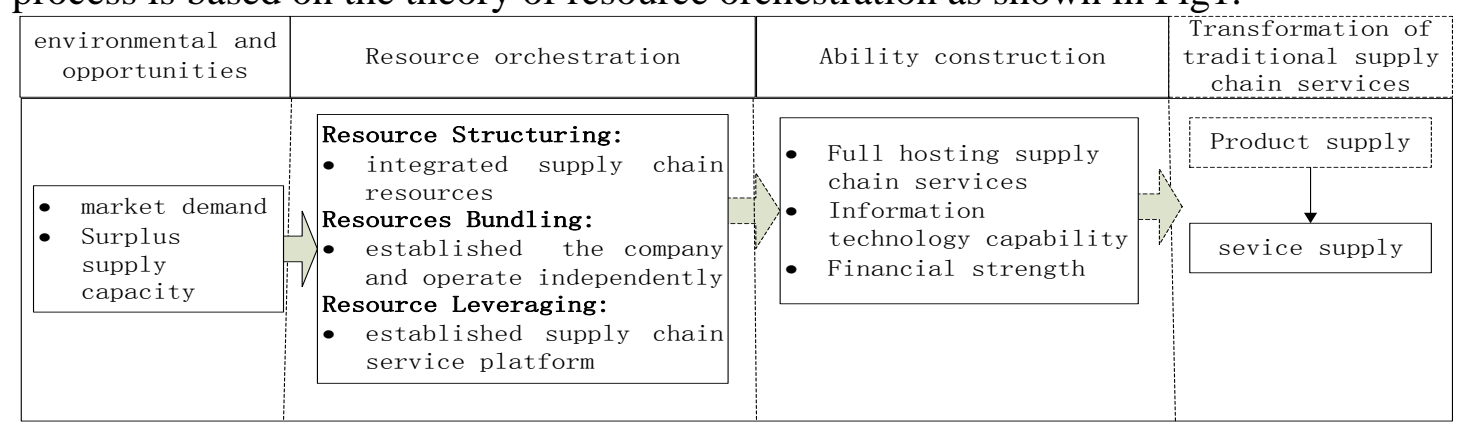

Fig. 1 Stage in the transformation of the traditional supply chain services

\subsection{Stage In Supply Chain Financial Service Innovation}

In September 2015, Shuhai decided to develop the supply chain finance. Shuhai has lots of reliable business data and loyal suppliers and customers, which provide the foundation for the supply chain finance.

In order to develp the supply chain finance better, Shuhai has also actively introduced the cooperation organization and established the good cooperation relations [7]. In addition, Shuhai also introduced the supply chain finance professionals, trained the exist staff, and set up a special group of supply chain fiannce, which was incorporated into the company's investment and financing departments, sharing of financial resources. The implementation of supply chain finance need to cooperate with the various business units, different financing modes have different process design and risk control, Shuhai established inter departmental business process of several existing financing mode, to reduce the risk of financing business.

Through the supply chain finance business, Shuhai has established a cooperative relationship with many financial institutions, which not only provide professional support for Shuhai, but also bring more project partners and clients. Supply chain financial services not only solve the financial needs of customers and obtain a certain financial gain, but also bring a lot of business improvement to the supply chain as a whole [8]. The whole process is based on the theory of resource orchestration as shown in Fig2.

\begin{tabular}{|c|c|c|c|}
\hline $\begin{array}{l}\text { environmental and } \\
\text { opportunities }\end{array}$ & Resource orchestration & Ability construction & $\begin{array}{c}\text { Catering supply } \\
\text { chain service } \\
\text { ecology }\end{array}$ \\
\hline $\begin{array}{ll}\text { - } & \text { Industry } \\
& \text { fund dilemma } \\
\text { - } & \text { Resource } \\
\text { base }\end{array}$ & $\begin{array}{l}\text { Resource Structuring: } \\
\text { - resource identification and } \\
\text { resource acquisition; } \\
\text { Resources Bundling: } \\
\text { - organizational structure } \\
\text { adjustment and resource } \\
\text { sharing } \\
\text { Resource Leveraging: } \\
\text { - leverage cooperative } \\
\text { resources and output service } \\
\text { capabilities }\end{array}$ & $\begin{array}{l}\text { - Asset side resource } \\
\text { advantage (good } \\
\text { supplier and customer) } \\
\text { The ability of } \\
\text { controling financial } \\
\text { risk } \\
\text { Capital side resource } \\
\text { advantage (good } \\
\text { financial resource) }\end{array}$ & $\begin{array}{l}\text { catering supply } \\
\text { chain finance } \\
\text { model leading by } \\
\text { core firm }\end{array}$ \\
\hline
\end{tabular}

\subsection{Case Conclusion}

Fig. 2 Stage in Supply chain financial service innovation

This paper mainly focuses on the supply chain finance services in catering enterprises, and discusses how to develop suitable supply chain finance mode for the enterprises on the basis of existing resources. Besides, dynamic process and the evolution mechanism of the development for supply chain finance services are explored from the theoretical perspective of resource orchestration.

(1) The core enterprise with the accumulation of resources in the industry over the years, familiar with the upstream and downstream firms' sales data, possible risks, the management situation, repayment ability, brand reputation, and so on, have advantageous industry resource advantages, which is a strong condition to lead enterprises develop supply chain finance. Shuhai is based on such an industry background and a core position in the supply chain. Moreover, Shuhai also systematically organized the existing resources and the need to introduce resources in the first stage, to structure resource combination. 
(2) From the perspective of resource orchestration, management and orchestration of resources for enterprises in different stages are different with the resources of each stages in dynamic changes and management. The resources obtained by Shuhai at each stage are resource base of the next stage and resources can be shared and can promote each other among the different departments of the enterprise. And the mutual promotion between supply chain finance business and the traditional supply chain business in Shuhai also shows that different businesses can realize the sharing of resources and promotion through a certain way.

\section{Conclusion}

This paper studies the supply chain finance based on the theory of resource arrangement, which is lack of application in China at present. But as a theory developed from resource base and asset scheduling, resource orchestration theory can explain the process and mechanism of dynamic management for enterprise resources better. Through the perspective of the theory of resource orchestration, this paper intends to implement the process research of the supply chain finance in catering industry, in order to reveal the formation mechanism of the suitable supply chain financing mode for the enterprises, and display the enterprises' actions in structuring, bundling and leveraging of resources more directly [9].

Besides, this paper studies the food supply chain finance with special characters of catering industry. At present, the mainstream of supply chain financing mode includes inventory financing, accounts receivable financing and prepayment financing, which cannot be directly applied in China's catering market. Shuhai is the leading enterprise in the domestic catering supply chain. This paper studies the process of Shuhai's supply chain finance and reveals how to step the planning of supply chain finance business with its own supply chain advantage, information resources and hardware resources.

\section{References}

[1] Gebauer H, Edvardsson B, Gustafsson A, et a1. Match or mismatch: Strategy-structure configurations in the service business of manufacturing companies [J]. Journal of Service Research, 2010, 13(2): 198-215.

[2] Baaon G J, Russell R B, Livingstone C D. Generation and interpretation of protein sequence and structural multiple alignments [J]. Journal of Protein Chemistry, 1992, 11(4): 389-389.

[3] Sirmon D G, Hitt M A, Ireland R D. Managing firm re- sources in dynamic environments to create value: Loo - king inside the black box [J]. Academy of management review, 2007, 32(1): $273-292$.

[4] Bridoux F, Smith K G, Grimm C M. The management of resources temporal effects of different types of actions on performance [J]. Journal of Management, 2013, 39 (4): 928-957.

[5] XU Hui, ZHANG Hai-jun. The building mechanism and evolutionary path of service innovation capability of manufacturers [J]. Studies in Science of Science, 2016, 34(2):298-311.

[6] Saulnier R J, Jacoby N H. The development of accounts receive-able financing [M]. Cambridge: NBER, 1943.

[7] Basu P, Nair S K. Supply chain finance enabled early pay: unlocking trapped value in B2B logistics [J]. International Journal of Logistics Systems and Management, 2012, 12(3): 334-353.

[8] Ren Wenchao. Material bank and its practice [J]. Scientific decision making, 1998, 2(2): 18-20.

[9] YANG Shao-hui. Research on Supply Chain Financing Service [J].Logistics Technology, 2005(10): 179-182. 